\title{
ОСОБЕННОСТИ ТЕЧЕНИЯ ПУБЕРТАТА У ДЕВОЧЕК С ВРОЖДЕННОЙ ГИПЕРПЛАЗИЕЙ НАДПОЧЕЧНИКОВ
}

\author{
${ }^{1}$ Логачева Т.М., ${ }^{1}$ Уколова И.Л., ${ }^{1}$ Логачев М.Ф., ${ }^{2}$ Карманов М.Е., ${ }^{2}$ Кувалдина Е.В.,

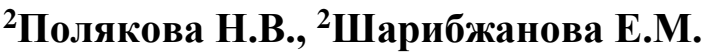 \\ ${ }^{1}$ ФАОУ ВО РНИМУ им. Н.И. Пирогова Минздрава России, г. Москва, Россия \\ ${ }^{2}$ ОСП РДКБ ФГАОУ ВО РНИМУ им. Н.И. Пирогова МЗ РФ, г. Москва, Россия
}

Актуальность: Одна из проблем пациенток с врожденной гиперплазией надпочечников (ВГН) заключается в снижении фертильности. Основными причинами ее снижения являются гиперандрогения надпочечникового происхождения и применение избыточных доз глюкокортикоидов вследствие неадекватно проводимой терапии. Регулярный менструальный цикл служит маркером нормального функционирования репродуктивной системы. Особенности течения пубертатного периода у девочек с ВГН изучены недостаточно.

Цель: исследовать особенности становление пубертата у девочек с ВГН в зависимости от формы болезни.

Материалы и методы: проведена оценка полового созревания у 75 девочек с сольтеряющей формой ВГН (58 пациенток) и простой вирильной формой ВГН (17 пациенток) в возрасте от 11 до 18 лет. Оценивались показатели SDS роста, полового созревания, возраст менархе и период становления менструальной функции.

Результаты: при оценке физического развития средние показатели SDS роста выявлены у 43\% (от общего числа пациентов). Преждевременное половое созревание (ППС) по гетеросексуальному типу отмечено у $20 \%$, из них $15 \%$ - с сольтеряющей формой ВГН. У 1 пациентки с вирильной формой выявлено сочетание ППС с ожирением. Средний возраст менархе в группе пациенток с простой вирильной формой ВГН составил 12.8 лет, тогда как у пациенток с сольтеряющей формой ВГН этот показатель - 14.2. Начало менструальной функции позже 15 лет отмечено у 18\% пациенток с вирильной формой ВГН и у $28 \%$ с сольтеряющей формой. Период становления менструальной функции в обеих группах протекал по типу олиго- и опсоменореи. У 29\% пациенток с вирильной формой отмечена вторичная аменорея.

Выводы: патологическое течение полового созревания и становления менструальной функции выявлено у девочек с ВГН в обеих группах. Снижение темпов роста встречается чаще в группе с простой вирильной формой. Частота выявления ППС по гетеросексуальному типу выше в группе пациенток с сольтеряющей формой ВГН. Возраст менархе в обеих группах не выходил за рамки среднестатистических показателей здоровых девочек, однако, стоит отметить, что средний возраст начала менструальной функции выше у пациенток с сольтеряющей формой болезни. Таким образом, у всех пациенток с ВГН, независимо от формы заболевания, выявлено нарушение полового созревания и патологическое течение пубертата, что обусловлено недостаточно адекватно подобранной заместительной терапией. Необходимы дальнейшие исследования по оптимизации заместительной терапии ВГН. 